\title{
Lutembacher's syndrome
}

\author{
Sandhya S. Kulkarni, Amit K. Sakaria, Sanket K. Mahajan, Kuldeep B. Shah \\ Department of Medicine, Krishna Institute of Medical Sciences University, Dhebewadi Road, Karad, \\ Dist. Satara, Maharashtra, India \\ Address for correspondence: Dr. Sakaria K. Amit, B/B/93, $8^{\text {th }}$ Floor, Mahavir Park, Behind Big Bazaar, \\ Pune-Satara Road, Pune-411037, Maharashtra, India.E-mail:dr.sakaria@hotmail.com
}

\begin{abstract}
The definition of Lutembacher's syndrome has undergone many changes. It refers to combination of congenital Atrial Septal Defect with acquired mitral stenosis. Lutembacher's syndrome is a very rare disease and in the past, it has been either overdiagnosed or misdiagnosed. Here, we will discuss a case of a pregnant lady who developed breathlessness during her third trimester of pregnancy and on detailed examination and investigation, she was found to be having Lutembacher's syndrome.
\end{abstract}

Key words: Atrial septal defect, Lutembacher's syndrome, mitral stenosis

\section{INTRODUCTION}

Lutembacher's syndrome refers to a congenital atrial septal defect (ASD) complicated by acquired mitral stenosis (MS). ${ }^{[1]}$ It comprises of Atrial Septal Defect (ASD) [Ostium Secundum] with Mitral stenosis (MS). Inter-atrial septum develops from two sources-septum primium and septum secundum. If defect is in the formation of septum primium-it leads to the formation of ASD (Primium) and if defect is in the formation of septum secundum it forms ASD (secundum). Here, we will discuss about a lady who was diagnozed as having Lutembacher's syndrome during her pregnancy for the first time.

\section{CASE REPORT}

A 22 year old female was referred Krishna Hospital as an unregistered case from a private maternity hospital in advanced pre-term labour. She had started labour pains one

\begin{tabular}{|l|l|}
\hline \multicolumn{2}{|c|}{ Access this article online } \\
\hline Quick Response Code: & Website: \\
\hline & www.jcdronline.com \\
\cline { 2 - 2 } & \\
\hline
\end{tabular}

day prior to admission to our hospital. She also complained of exertional dyspnoea (New York Heart Association NYHA Class II) which was gradually progressing since a day before onset of labour pains, and orthopnoea. There was no history of accompanying chest pain, cough, palpitations, fever, or symptoms of upper respiratory infections. There was no preceding or accompanying vaginal bleeding. There was no past history of joint pains with throat infection, or any long term medications for any premorbid condition. She was married since five years, without consanguinity and had a first full term normal home delivery (a male child) $2^{1 / 2}$ years ago. (Obstetric score $\left.\mathrm{G}_{2} \mathrm{P}_{1} \mathrm{~L}_{1} \mathrm{~A}_{0}\right)$. In the present pregnancy, she never attended ante natal care (ANC) clinic.

On examination in our hospital, she was afebrile with normal volume regular pulse of 86 beats/min and blood pressure $110 / 70 \mathrm{~mm}$ of $\mathrm{Hg}$, with respiratory rate of 20 breaths $/ \mathrm{min}$. She was pale and showed bipedal oedema. In cardiac examination, there was loud mitral $\mathrm{S}_{1}$, and wide fixed split pulmonary $\mathrm{S}_{2}$ with opening snap in mitral area. There was III/IV mid diastolic murmur in mitral area and early systolic murmur, and non-radiating short murmur in pulmonary area. There was no parasternal heave. Respiratory system examination revealed bilaterally equal normal breath sounds with bilateral lower zones endinspiratory fine crackles. Abdominal examination revealed 
no hepatomegaly and uterus at levels of 35 weeks gestation. Per vaginal examination revealed patulous, minimally effaced cervix with dilation of $2 \mathrm{~cm}$, with presenting part being Vertex at station -3 with adequate pelvis size.

Her investigation reports were as follows:

- Hemoglobin (Hb)-11.5 gm\%;

- White blood cells (WBC) - 12,100/cu mm of blood;

- Polymorphs - 54\%;

- Lymphocytes - $44 \%$;

- Eosinophils - 02\%;

- Platelet count - 1.85 lakh;

- Random blood sugar - $76 \mathrm{mg} / \mathrm{dl}$;

- Blood urea - $25 \mathrm{mg} / \mathrm{dl}$; [normal value $\rightarrow 20-40 \mathrm{mg} / \mathrm{dl}$ ]

- Serum creatinine $-0.8 \mathrm{mg} / \mathrm{dl}$; [normal value $\rightarrow$ $0.8-1.6 \mathrm{mg} / \mathrm{dl}]$

- Serum sodium - $135 \mathrm{mEq} / \mathrm{L}$; [normal value $\rightarrow$ $135-145 \mathrm{mEq} / \mathrm{L}]$

- Serum potassium - $5.1 \mathrm{mEq} / \mathrm{L}$. [normal value $\rightarrow 3.5-$ $5.5 \mathrm{mEq} / \mathrm{L}]$

Urine Routine and Microscopic exam was Normal.

Electrocardiogram [Figure 1] $\rightarrow$ Normal Sinus Rhythm; Incomplete Right Bundle Branch Block (RBBB); Left Atrial Enlargement; Normal PR Interval/Normal Qtc.

2D-Echocardiography [Figures 2 and 3] $\rightarrow$ Moderate Mitral stenosis; Mild Mitral regurgitation; mitral valve area 1.42-1.45 $\mathrm{cm}^{2}$. Large Ostium Secondum atrial septal defect With Left To Right Shunt; Mild pulmonary arterial hypertension.

Other Valves- Normal. No Clots/No Effusion/No Vegetations.

With the above history and findings, a medicine consult was sought by the department of obstetrics and gynaecology, and she was allowed to continue the labour after giving her injectable furosemide to relieve her of pulmonary congestion. The diuretics were then continued and she was also started on the standard prophylaxis for Rheumatic Fever with Benzathine Penicillin 12 lakh units deep intramuscular (After Skin Test Dose) once every 3 weeks. She delivered a live female baby of $2.120 \mathrm{~kg}$. She was advised surgical intervention at a later date, after Trans-Oesophageal Echocardiography. She was also advised tubal ligation to avoid further cardiac compromise which she agreed to, and she was posted for the same procedure later. She was discharged in a haemodynamically stable condition. Later on she came

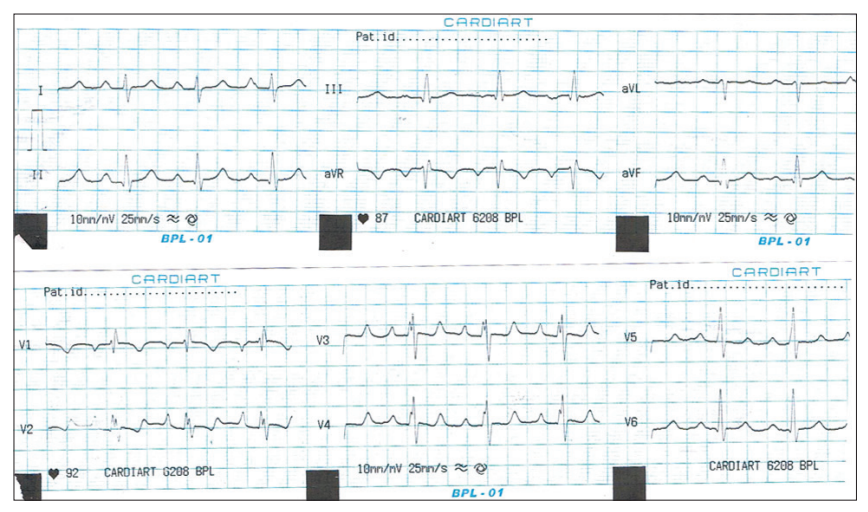

Figure 1: Electrocardiogram of patient of Lutembacher's syndrome suggestive of incomplete right bundle branch block with left atrial enlargement

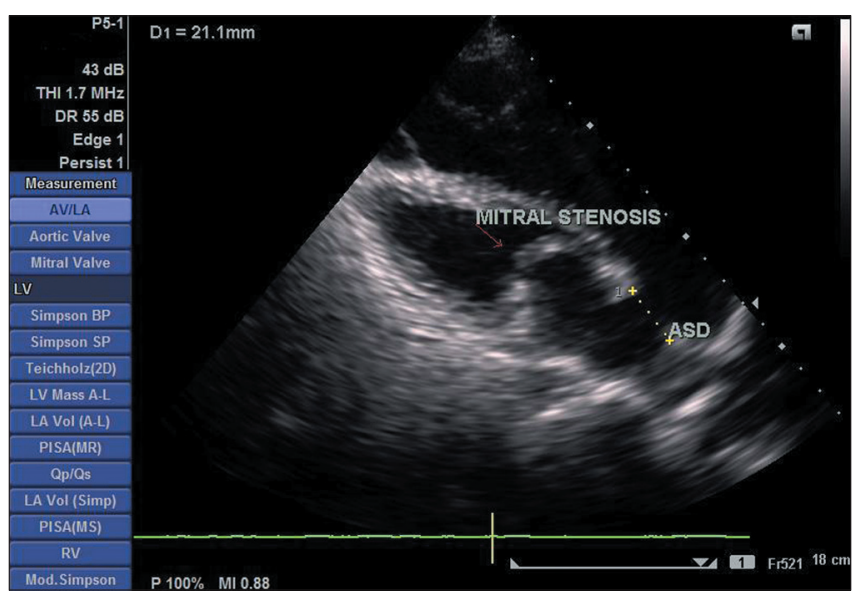

Figure 2: Transthoracic echocardiogram of patient of Lutembacher's syndrome showing thickened mitral leaflets with doming of anterior mitral leaflet with mitral stenosis and atrial septal defect

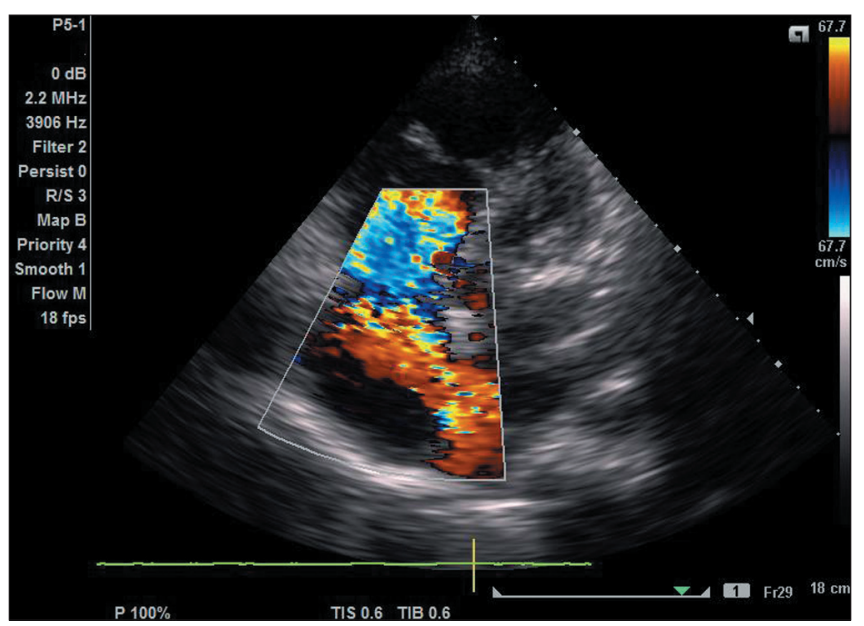

Figure 3: Transthoracic echocardiogram colour doppler of patient of Lutembacher's syndrome showing flow from left atrium to right atrium through atrial septal defect

for rheumatic fever prophylaxis as scheduled for initial 2 months after which she has not returned for a follow up, and at the same time she was not willing for any kind of intervention due to financial constraints. 


\section{DISCUSSION}

In Lutembacher's syndrome, initially, high left atrial pressure due to mitral stenosis was thought to stretch open the patent foramen ovale, causing left-to-right shunt and providing another outlet for the left atrium. Now ASD in this syndrome, like mitral stenosis, is recognized as being either congenital or acquired, as already described. The haemodynamic effects of this syndrome are a result of the interplay between the relative effects of ASD and mitral stenosis. In its initial description, the ASD was typically large in Lutembacher syndrome, thus providing another route for blood flow. The direction of blood flow is determined largely by the compliance of left and right ventricles. Normally, the right ventricle is more compliant than the left ventricle. As a result, in the presence of mitral stenosis, blood flows to the right atrium through the ASD instead of going backward into the pulmonary veins, thus avoiding pulmonary congestion. This happens at the cost of progressive dilatation and, ultimately, failure of the right ventricle and reduced blood flow to the left ventricle. Development of Eisenmenger syndrome or irreversible pulmonary vascular disease is very uncommon in the presence of large ASD and high left atrial pressure because of mitral stenosis.

The incidence of this condition is very rare. In one study published in American Heart Journal in 1997, it is found that the incidence of Lutembacher's syndrome is$0.001 / 10,00000 .{ }^{[2]}$ The ameliorating role of the ASD in MS was evident in Lutembacher's original report of 1916; the patient was a 61-year-old woman who had been pregnant seven times. ${ }^{[3]}$ An earlier case report in the literature in 1880 (and referred to by Perloff) ${ }^{[1]}$ was of a 74-year-old woman who had endured 11 pregnancies. Survival to advanced age has also been reported; ${ }^{[4]}$ in one instance an 81-year-old woman experienced no symptoms related to her heart disease until she reached 75 years of age. ${ }^{[4]}$ These favourable reports, however, should not obscure the fact that the long-term natural history of ASD is unfavourably influenced by MS, which augments the left-to-right shunt and predisposes to atrial fibrillation and right ventricular failure. ${ }^{[5]}$ The presence of MS, especially when accompanied by mitral regurgitation, increases susceptibility to infective endocarditis, in contrast to the low incidence of infective endocarditis in uncomplicated ASD, ${ }^{[1]}$ just like in our case. Early diagnosis and surgical treatment bears a good prognostic value. If patient is diagnosed at late stage, pulmonary hypertension and heart failure develops and the prognosis is bad. ${ }^{[6]}$ If the patient is diagnozed earlier before the development of pulmonary hypertension and heart failure, - ASD closure with mitral valve replacement bears a good prognosis and prolongs survival.

\section{REFERENCES}

1. Perloff JK. The clinical recognition of congenital heart disease. $4^{\text {th }}$ ed. Philadelphia: Saunders; 1994. p. 323-8.

2. Ali SY, Rahman M, Islam M, Barman RC, Ali MY, Islam MMSU et al. Lutembacher's Syndrome- A Case Report. Faridpur Med Coll J 2011;6:59-60.

3. Lutembacher R. De la sténose mitrale avec communication interauriculaire. Arch Mal Coeur 1916;9:237-60.

4. Rosenthal L. Atrial septal defect with mitral stenosis (Lutembacher's syndrome) in a woman of 81. Br Med J 1956;2:1351.

5. Cheng TO. Coexistent atrial septal defect and mitral stenosis (Lutembacher syndrome): An ideal combination for percutaneous treatment. Cathet Cardiovasc Intervent 1999;48:205-6.

6. Levin AR, Spach MS, Boimeau JP, Canent RV Jr, Capp MP, Jewett PH. Atrial Pressure flow dynamics and atrial septal defects (Secundum type). Circulation 1968;37:476-88.

How to cite this article: Kulkarni SS, Sakaria AK, Mahajan SK, Shah KB. Lutembacher's syndrome. J Cardiovasc Dis Res 2012;3:179-81. Source of Support: Nil, Conflict of Interest: None declared. 